Research Paper

\title{
Prognostic value of transglutaminase 2 in non-small cell lung cancer patients
}

\author{
Zhu Chihong ${ }^{1, *}$, Ling Yutian ${ }^{1, *}$, Wan Danying ${ }^{1}$, Jiang Ruibin ${ }^{1}$, Sheng Huaying ${ }^{1}$, Gu \\ Linhui ${ }^{1,2}$ and Feng Jianguo $0^{1,2}$ \\ ${ }^{1}$ Cancer Research Institute, Zhejiang Cancer Hospital, Hangzhou, Zhejiang 310022, China \\ ${ }^{2}$ Key Laboratory Diagnosis and Treatment Technology on Thoracic Oncology, Hangzhou, Zhejiang 310022, China \\ *These authors have contributed equally to this work \\ Correspondence to: Gu Linhui, email: linhuigu@yeah.net \\ Feng Jianguo, email: fengjg@zjcc.org.cn
}

Keywords: TG2, NSCLC, prognosis

Abbreviations: TG2: Transglutaminase 2; NSCLC: non-small cell lung cancer

Received: November 23, $2016 \quad$ Accepted: February 20, 2017

Published: April 24, 2017

Copyright: Chihong et al. This is an open-access article distributed under the terms of the Creative Commons Attribution License 3.0 ( $C$ C BY 3.0), which permits unrestricted use, distribution, and reproduction in any medium, provided the original author and source are credited.

\section{ABSTRACT}

\begin{abstract}
Transglutaminase 2 (TG2) plays important roles in cell survival and cancer progression. In this study, we examined TG2 expression in specimen of 194 patients diagnosed with non-small cell lung cancer (NSCLC), and found that the TG2 gene expression was significantly higher in lung cancer tissues as compared to paired incisal marginal tissues or normal tissues. Our data revealed that patients with lower level of TG2 expression detected in cancer tissues had longer disease free survival and overall survival as compared to the patients with higher TG2 expression. We also found that TG2 expression level correlated to NSCLC recurrence. These results suggest a potential prognosis impact of TG2 for NSCLC patients.
\end{abstract}

\section{INTRODUCTION}

Lung cancer remains one of the leading causes of cancer mortality worldwide [1]. The majority of lung cancer is NSCLS (non-small-cell lung cancer), and one third of these patients are diagnosed with stage III disease when curative treatment is extremely limited [2]. Despite the tremendous efforts and progress in lung cancer research, and the use of aggressive multimodal chemoand radiotherapy, the overall treatment outcomes for these NSCLC patients remain poor, and corresponding 5-year survival rates were $54 \%$ for patients with localized tumor, $26.55 \%$ for patients with regional metastasis, and $4 \%$ for patients with distant metastasis [3].

Cancer prognostic biomarkers are patient or tumor characteristics that predict clinical outcome independent of the treatment [4], and the goal of identifying prognostic biomarkers is to define patient subpopulations with significantly different anticipated outcomes, who might benefit from different therapies. In lung cancer, clinically relevant prognostic information is provided by staging according to the database of The International Association for the study of Lung Cancer (IASLC)[5]. However, increasing evidences have suggested significant roles for more than 100 biomarkers, which may well provide some biological insight, in evaluation of patient prognosis with NSCLC [6-11]. However, most of these potential biomarkers do not reach clinical implementation, and it takes time to prove the clinical relevance for these recently identified potentially biomarkers [6].

In this study, we investigated the expressions of Transglutaminase 2 (TG2), a member of Transglutaminases family, in NSCLC tumors. Our results showed that the TG2 gene expression was significantly higher in lung cancer tissues as compared to paired incisal marginal tissues or normal tissues. The data also showed that patients with lower level of TG2 expression detected in cancer tissues had longer disease free survival and overall survival as compared to the patients with higher TG2 expression, and TG2 expression level correlated to NSCLC recurrence. Our results present here thus revealed a potential prognosis value of TG2 for NSCLC patients. 


\section{RESULTS}

\section{Patients' characteristics}

Among 194 patients, there were 155 men and 39 women with age ranging from 37 to 76 years old (mean 60.08 \pm 8.56 ). 81 cases were diagnosed with adenocarcinoma, 110 cases with squamous cell carcinoma and other 3 cases large cell carcinoma, epidermoid carcinoma and mucoepidermoid carcinoma for each. 53 cases were diagnosed at stage I, 82 cases at stage II and 52 cases at stage III. 167 cases were with family cancer history, and 168 cases were with smoking history and 167 cases with alcohol use history.

\section{TG2 mRNA and protein expressions in NSCLC}

The expression of TG2 gene in tumor tissues, incisal marginal tissues and normal tissues from these 194 patients were measured using real-time PCR. The relative
mRNA expressions, as compared to their own actin, were $22.85 \pm 45.15,12.49 \pm 126.33$ and $6.16 \pm 15.60$, respectively (Figure 1). These results showed a trend of TG2 mRNA expression towards to lower expression in lung cancer tissues, marginal tissues and normal tissues. The difference of TG2 mRNA expression in lung cancer tissues versus in marginal tissues, or in lung cancer tissues versus in normal tissues or in incisal marginal tissues versus in normal tissues were all with statistical significance $(\mathrm{P}$ all $<0.001)$.

In addition, we detected positive TG2 immunostaining in 75 cases of tumor tissues (38.7\%), with the IHC performed in the tissue microarray containing 194 paired specimen (Figure 2).

\section{Relationship of TG2 mRNA and protein expressions with Clinical-Pathological Factors in NSCLC}

Nonparametric and chi-square tests showed that TG2 mRNA and protein expression were associated with

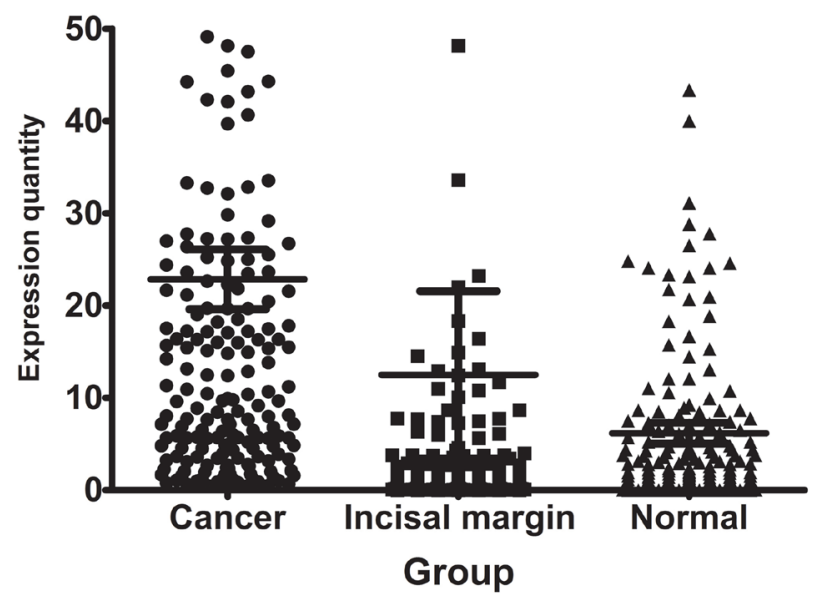

Figure 1: The expression of TG2 gene in paried NSCLC tumor, incisal marginal and normal tissues. The difference in TG2 mRNA expression between lung cancer tissues and marginal tissues, lung cancer tissues and normal tissues, incisal marginal tissues and normal tissues were all significantly different $(\mathrm{P}$ all $<0.001)$.
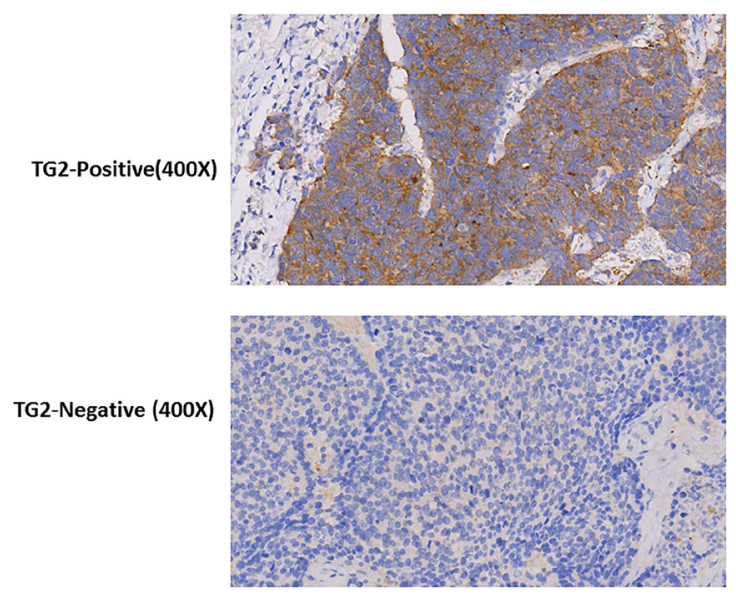

Figure 2: Representative images showing the immunostaining of TG2 protein in TMA. 
Table 1: Association of TG2 mRNA level with clinicapathological factors in patients with NSCLC

\begin{tabular}{|c|c|c|c|c|c|c|}
\hline \multirow[b]{2}{*}{ Factors } & \multirow{2}{*}{$\begin{array}{l}\text { Patients, } \\
\text { n(\%) }\end{array}$} & TG2 & \multirow[b]{2}{*}{$\boldsymbol{P}$} & \multicolumn{2}{|c|}{ TG2 } & \multirow[b]{2}{*}{$\boldsymbol{P}$} \\
\hline & & Median (Mean, $5^{\text {th }}-95^{\text {th }}$ ) & & $\begin{array}{c}\text { Low expression } \\
n(\%)\end{array}$ & $\begin{array}{c}\text { High expression } \\
\text { n(\%) }\end{array}$ & \\
\hline Sex & & & 0.947 & & & 0.858 \\
\hline Male & $155(80.7)$ & $11.54(22.97,15.51-30.44)$ & & $77(42.1)$ & $78(38.6)$ & \\
\hline Female & $39(19.3)$ & $10.92(21.61,13.74-29.47)$ & & $20(7.9)$ & $19(11.4)$ & \\
\hline Age(years) & & & 0.450 & & & 0.565 \\
\hline$\leq 60$ & $90(69.3)$ & $4.51(4.67,4.06-5.27)$ & & $47(34.3)$ & $43(35.0)$ & \\
\hline$>60$ & $104(30.7)$ & $26.38(40.57,29.23-51.91)$ & & $50(15.7)$ & $54(15.0)$ & \\
\hline Family History & & & 0.827 & & & 0.186 \\
\hline no & $136(80)$ & $10.68(20.82,16.76-24.89)$ & & $70(43.6)$ & $66(36.4)$ & \\
\hline yes & $31(16.4)$ & $9.85(36.88(1.51-72.24)$ & & $17(6.4)$ & $14(10)$ & \\
\hline Smoking & & & 0.960 & & & 0.510 \\
\hline Never & $39(22.1)$ & $9.92(21.89,13.69-30.10)$ & & $22(9.3)$ & $17(12.9)$ & \\
\hline Ever/Current & $129(74.3)$ & $11.11(24.45,15.63-33.28)$ & & $65(40.7)$ & $64(33.6)$ & \\
\hline Alcohol & & & 0.212 & & & 0.329 \\
\hline Never & $77(44.3)$ & $13.15(22.42,17.10-27.74)$ & & $36(20.7)$ & $41(23.6)$ & \\
\hline Ever/Current & $90(54.3)$ & $9.64(25.29,13.06-37.53)$ & & $50(27.9)$ & $40(26.4)$ & \\
\hline Histologic type & & & 0.402 & & & 0.011 \\
\hline $\begin{array}{l}\text { Squamous cell } \\
\text { carcinoma }\end{array}$ & $110(57.1)$ & $10.93(23.35,12.69-34.02)$ & & $46(33.6)$ & $64(23.6)$ & \\
\hline Adenocarcinoma & $81(35.7)$ & $14.81(22.70,17.43-28.00)$ & & $49(12.1)$ & $32(23.6)$ & \\
\hline Others $^{\mathrm{a}}$ & $3(7.1)$ & $3.58(8.34,-16.19-32.87)$ & & $2(4.3)$ & $1(2.9)$ & \\
\hline Grade & & & 0.004 & & & 0.010 \\
\hline high-middle & $93(46.4)$ & $9.66(19.58,14.70-24.46)$ & & $60(19.3)$ & $33(2.71)$ & \\
\hline middle-low & $88(46.4)$ & $18.87(35.51,12.57-38.45)$ & & $40(28.6)$ & $48(17.9)$ & \\
\hline Clinical stage & & & 0.03 & & & 0.018 \\
\hline I & $53(37.9)$ & $3.04(7.58,0.32-21.76)$ & & $35(22.9)$ & $18(15.0)$ & \\
\hline II & $82(27.9)$ & $8.02(8.60,0.14-23.08)$ & & $42(15.7)$ & $40(12.1)$ & \\
\hline III & $52(34.3)$ & $12.42(14.71,0.27-24.97)$ & & $20(19.3)$ & $32(15.0)$ & \\
\hline
\end{tabular}

$p<.05$ were highlighted in bold.

NSCLC histologic type, stage and Tumor differentiation. TG2 mRNA and protein level were also significantly lower in Squamous cell carcinoma, early stage and well-differentiated (high to middle grade) tumors when comparing to adenocarcinoma, advanced stage and middle to low grade of tumors ( $\mathrm{P}$ all $<0.05$ ), respectively (Table 1 and 2). We did not observe any correlations between expression of TG2 and clinical features of age, gender and family cancer history. Of note, histories for smoking and drinking may also correlate to TG2 mRNA level and/or protein expression.

\section{Relationship of TG2 mRNA and protein expressions with disease progression and overall survival in NSCLC}

With Kaplan-Meier analysis and log-rank test, our data showed a strong correlation between the TG2 mRNA and/or protein expressions and the disease progress (tumor relapse and metastasis). The lower level of relative expression of TG2 mRNA and protein indicated dramatically longer disease-free survival (DFS) as compared to the patients with tumors expressing higher 
Table 2: Association of TG2 protein level with clinicapathological factors in patients with NSCLC

\begin{tabular}{|c|c|c|c|c|}
\hline \multirow[b]{2}{*}{ Factors } & \multirow[b]{2}{*}{ Patients, n(\%) } & \multicolumn{2}{|c|}{ TG2 } & \multirow[b]{2}{*}{$P$} \\
\hline & & $\begin{array}{c}\text { Negative } \\
\text { n(\%) }\end{array}$ & $\begin{array}{c}\text { Positive } \\
\text { n(\%) }\end{array}$ & \\
\hline Sex & & & & 0.734 \\
\hline Male & $155(80.7)$ & $96(42.1)$ & $59(38.6)$ & \\
\hline Female & $39(19.3)$ & $23(7.9)$ & $16(11.4)$ & \\
\hline Age(years) & & & & 0.951 \\
\hline$\leq 60$ & $90(69.3)$ & $55(34.3)$ & $35(35.0)$ & \\
\hline$>60$ & $104(30.7)$ & $64(15.7)$ & $40(15.0)$ & \\
\hline Family History & & & & 0.227 \\
\hline no & $136(80)$ & $76(43.6)$ & $60(36.4)$ & \\
\hline yes & $31(16.4)$ & $21(6.4)$ & $10(10)$ & \\
\hline Smoking & & & & 0.007 \\
\hline Never & $39(22.1)$ & $30(9.3)$ & $9(12.9)$ & \\
\hline Ever/Current & $129(74.3)$ & $68(40.7)$ & $61(33.6)$ & \\
\hline Alcohol & & & & 0.0001 \\
\hline Never & $77(44.3)$ & $55(20.7)$ & $22(23.6)$ & \\
\hline Ever/Current & $90(54.3)$ & $39(27.9)$ & $51(26.4)$ & \\
\hline Histologic type & & & & 0.001 \\
\hline $\begin{array}{l}\text { Squamous cell } \\
\text { carcinoma }\end{array}$ & $110(57.1)$ & $56(33.6)$ & $54(23.6)$ & \\
\hline Adenocarcinoma & $81(35.7)$ & $61(12.1)$ & $20(23.6)$ & \\
\hline Others $^{\mathrm{a}}$ & $3(7.1)$ & $2(4.3)$ & $1(2.9)$ & \\
\hline Grade & & & & 0.015 \\
\hline high-middle & $93(46.4)$ & $63(19.3)$ & $30(2.71)$ & \\
\hline middle-low & $88(46.4)$ & $44(28.6)$ & $44(17.9)$ & \\
\hline Clinical stage & & & & 0.001 \\
\hline I & $53(37.9)$ & $42(22.9)$ & $11(15.0)$ & \\
\hline II & $82(27.9)$ & $48(15.7)$ & $34(12.1)$ & \\
\hline III & $52(34.3)$ & $22(19.3)$ & $30(15.0)$ & \\
\hline
\end{tabular}

levels of TG2 mRNA and protein expression $(\mathrm{P}<0.05)$. Patients with tumors expressing lower levels of TG2 mRNA and protein also had better overall survival (OS) rates when comparing to the patients with tumors expressing higher levels of TG2 mRNA and protein $(\mathrm{P}<0.05)$. (Figure 3).

\section{Survival analysis}

By using Cox regression analysis, we found that TG2 mRNA and protein expression significantly correlated with the DFS and OS. Our data also indicated that Gender, clinical stages and smoking history of these NSCLC patients may also correlated with the DFS and OS. However, no evidence showed that clinical features of age, drinking history, family cancer history, histologic type and tumor grade had correlations with the DFS and OS (Table 3-4).

\section{DISCUSSION}

Transglutaminase 2 (TG2) is a ubiquitous multifunctional mammalian protein that catalyzes the formation of intermolecular isopeptide bonds between glutamine and lysine residues of several proteins $[14,15]$. 
Table 3: Survival model by Cox regression analysis for DFS and OS of TG2-mRNA and clinicopathological characteristics

\begin{tabular}{|c|c|c|c|c|c|c|}
\hline \multirow{2}{*}{ Variable } & \multicolumn{3}{|c|}{ DFS } & \multicolumn{3}{|c|}{ OS } \\
\hline & $\operatorname{Exp}(B)$ & $95 \% \mathrm{CI}$ & P Value & $\operatorname{Exp}(B)$ & $95 \% \mathrm{CI}$ & P Value \\
\hline TG2-mRNA & 2.02 & $1.23-3.35$ & 0.006 & 2.07 & $1.20+3.58$ & 0.009 \\
\hline Age & 1.16 & $0.71-1.91$ & 0.540 & 1.02 & $0.58-1.77$ & 0.954 \\
\hline Sex & 0.10 & $0.03-0.32$ & 0.000 & 0.14 & $0.04-0.55$ & 0.005 \\
\hline Smoking & 0.69 & $0.34-1.40$ & 0.001 & 0.34 & $0.12-0.95$ & 0.039 \\
\hline Drinking & 1.18 & $0.69-2.00$ & 0.551 & 1.37 & $0.77-2.45$ & 0.290 \\
\hline FamilyHistoy & 0.85 & $0.34-1.39$ & 0.290 & 1.68 & $0.87-3.27$ & 0.125 \\
\hline Histologic type & 1.45 & $0.87-2.36$ & 0.140 & 0.85 & $0.48-1.50$ & 0.572 \\
\hline Grade & 0.85 & $0.52-1.40$ & 0.529 & 0.72 & $0.42-1.25$ & 0.245 \\
\hline Clinical stage & 1.74 & $1.05-2.91$ & 0.033 & 4.01 & $2.23-7.2$ & 0.000 \\
\hline
\end{tabular}

Table 4: Survival model by Cox regression analysis for DFS and OS of TG2-protein and clinicopathological characteristics

\begin{tabular}{|c|c|c|c|c|c|c|}
\hline \multirow{2}{*}{ Variable } & \multicolumn{3}{|c|}{ DFS } & \multicolumn{3}{|c|}{ OS } \\
\hline & $\operatorname{Exp}(B)$ & $95 \% \mathrm{CI}$ & P Value & $\operatorname{Exp}(B)$ & $95 \% \mathrm{CI}$ & P Value \\
\hline TG2-Protien & 2.29 & $1.39-3.79$ & 0.001 & 2.60 & $1.50-4.49$ & 0.001 \\
\hline Age & 1.24 & $0.76-2.04$ & 0.384 & 1.12 & $0.65-1.93$ & 0.679 \\
\hline Sex & 0.09 & $0.03-0.31$ & 0.000 & 0.11 & $0.03-0.43$ & 0.002 \\
\hline Smoking & 0.20 & $0.08-0.51$ & 0.001 & 0.26 & $0.09-0.74$ & 0.011 \\
\hline Drinking & 1.67 & 0.69-1.99 & 0.243 & 1.34 & $0.75-239$ & 0.325 \\
\hline FamilyHistoy & 0.66 & $0.32-1.33$ & 0.243 & 1.46 & $0.75-2.84$ & 0.267 \\
\hline Histologic type & 1.34 & $0.82-2.19$ & 0.242 & 0.79 & $0.45-1.38$ & 0.404 \\
\hline Grade & 0.91 & $0.59-1.48$ & 0.70 & 0.77 & $0.45-1.32$ & 0.347 \\
\hline Clinical stage & 1.71 & $1.03-2.84$ & 0.040 & 3.72 & $2.09-6.62$ & 0.000 \\
\hline
\end{tabular}
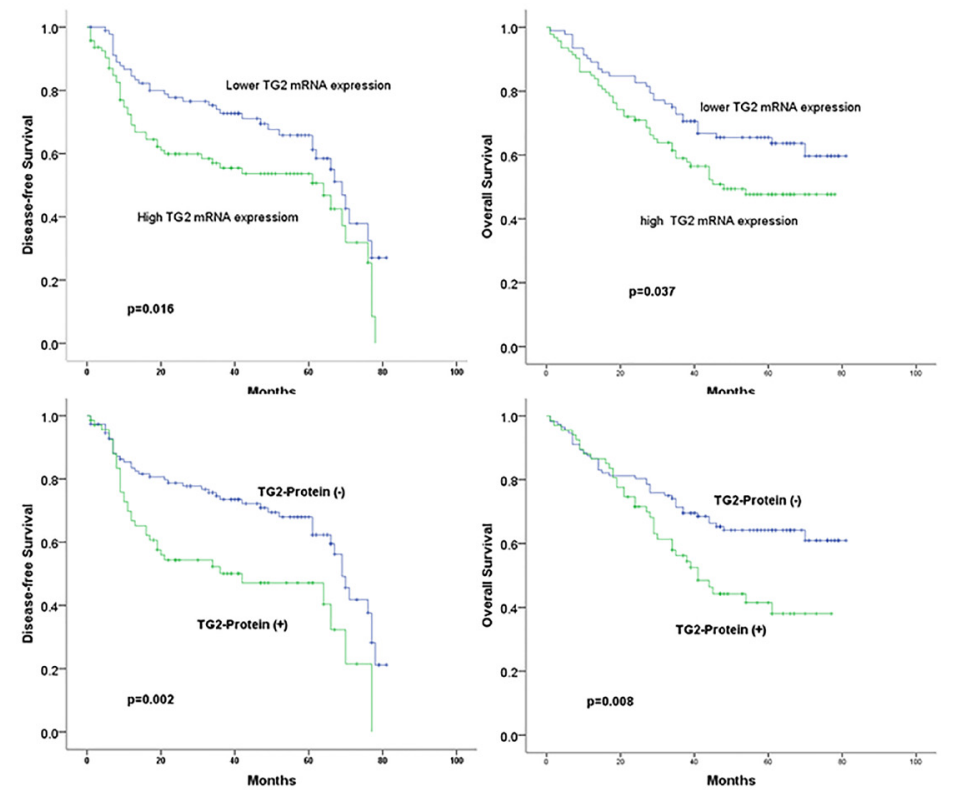

Figure 3: Correlation of TG2 expression with PFS and OS in NSCLC. Top: correlations of TG2 mRNA expression with PFS and OS in NSCLC; bottom: correlations of TG2 protein expression with PFS and OS in NSCLC. 
The enzymatic activity of TG2 is allosterically regulated by several factors, including guanine nucleotides, $\mathrm{Ca}+2$, and redox potential [16]. TG2 has been found to be involved in a diverse range of biological processes, including apoptosis, membrane signaling, cell adhesion and extracellular matrix formation, and elevated expression of TG2 was detected in various forms of cancer. For example, studies have reported that cancer cells failing to apoptosis expressed high levels of TG2 [17], and increased expression of TG2 could prolong cell survival by preventing apoptosis [18]. Studies further demonstrated that TG2 could interact with the proteins such as $\mathrm{pRb}$, integrins and fibronectin to induce activation of cell survival and antiapoptotic signaling pathways and prevent cancer cells from apoptosis $[19,20]$. Other studies reported that cancer cells with developed resistance to chemotherapeutic drugs exhibited extraordinary high levels of TG2 expression compared with the parental cell line from which they were derived [21-24], and downregulation of TG2 expression or inhibition of TG2 enzymatic activity can convert chemoresistance in cancer cells $[25,26]$. In our previous study, we also reported that treatment with TG2 inhibitor increase radiosensitivity in human lung cancer cells [27]. In addition, TG2 expression was also reported to induce Epithelial-to-Mesenchymal Transition (EMT) which result in the increased invasiveness of cancer cells $[28,29]$. These evidences thus suggest that TG2 may play important roles in cancer cell survival and cancer metastasis or recurrence during clinical treatment. Of note, Jeong JH et al. has recently reported that TG2 expression correlated to the DFS and progression-free survival (PFS) for NSCLC in a small cohort containing enrolling 29 patients [30]. In another study with a larger cohort containing 429 NSCLC cases, Choi CM., et al. has also reported significant correlation between strong TG 2 expression and shorter DFS in the non-adenocarcinoma subtype of NSCLC, but they did not identify similar correlation in the adenocarcinoma subtype [31]. Our data form a cohort with 194 NSCLC cases, however, showed strong correlations of TG2 expression with DFS and with OS in overall NSCLC patients diagnosed with both non-adenocarcinoma subtype and adenocarcinoma subtype of cancers. Nevertheless, these observation and reports suggest a potential clinical impact of TG2 as a prognostic biomarker for NSCLC patients. However, further studies, including the studies for correlation of TG2 expression with other prognostic marker for NSCLC, are needed.

\section{MATERIALS AND METHODS}

\section{Primary tumor tissues and patients}

194 primary tumor tissues and paired adjacent nontumor tissues or incisal marginal tissues were collected from surgical specimens of NSCLC patients between March 2006 and April 2010 in Zhejiang Cancer Hospital. All the patients did not receive any anticancer therapy such as chemotherapy and radiotherapy, or other treatments prior to surgery. Paired nontumor samples were obtained at least $2 \mathrm{~cm}$ distant from the tumor and incisal marginal tissues were obtained within $2 \mathrm{~cm}$ distant from the tumor. Informed consent was obtained from all patients, and the study was reviewed and approved by the Clinical Research Ethics Committee of the Zhejiang Cancer Hospital. The histological diagnosis was based on the classification criteria for lung tumors of the World Health Organization and International Association for the Study of Lung Cancer (WHO/IASLC). The tumor stage was defined according to the seventh edition of tumor-nodemetastasis (TNM) classification.

\section{Follow-up}

All patients received standardized follow-up with patients themselves or family members up to March 15, 2015. Among all 194 patients, 82 patients had relapse during the follow-up, with 75 patients died, 5 patients had no record of distal metastasis and 15 patients had no record of overall survival.

\section{RNA extraction}

Lung tissues (about $2 \mathrm{~g}$ ) were first homogenized using Qiagen Tissue Lyser (Qiagen, Valencia,CA, USA) and then total RNA were extracted using DNA/ RNA/Protein mini kit according to the manufacturer's instructions (Qiagen). The concentration and purity of RNA were measured with nanodrop 1000 (NanoDrop, Wilmington, DE, USA).

\section{Real-time reverse transcription-PCR}

A reverse transcription reaction was performed using $1 \mu \mathrm{g}$ of total RNA with Prime Script RT Reagent (200) Kit (Takara No. DRR037A). The RNA expression levels of TG2 were determined by real-time RT-PCR using SYBR ${ }^{\circledR}$ Premix Ex Taq ${ }^{\mathrm{TM}}$ (Tli RNaseH Plus)(Takara No. DRR420A) and ABI 7500 Real-time PCR System (Life Technology, Foster City, CA, USA). The primers used in this study were designed based on the sequences information from NCBI database, and synthesized by Takara Bio Inc. The forward primer for TG2 was 5'CCTGATCGTTGGGCTGAAG-3' and the reverse primer was 5'- TCGGCCAGTTTGTTCAGGTG-3'. The length of PCR product was $144 \mathrm{bp}$. The $\beta$-actin was used as internal control of RNA integrity, with the forward primer of 5'TGGCACCCAGCACAATGAA-3' and the reverse primer of 5'- CTAAGTCATAGTCCGCCTAGAAGCA-3'. The length of PCR product for $\beta$-actin was $186 \mathrm{bp}$. RT-PCR was carried out using the following conditions: $10 \mathrm{~min}$ at $95^{\circ} \mathrm{C}$, followed by 40 cycles at $95^{\circ} \mathrm{C}$ for $15 \mathrm{~s}$ and $60^{\circ} \mathrm{C}$ for $1 \mathrm{~min}$. A melting curve analysis program was used to verify the authenticity of the PCR products by their specific melting temperatures (Tm) after amplification according to manufacturer's instructions. The cycle 
threshold $(\mathrm{Ct})$ values were determined by the SDS software that was installed in the real-time PCR machine. The relative TG2 gene expression in different lung tissues was calculated using $2^{-\Delta \Delta \mathrm{Ct}}$ method as compared to its own actin level which was described before [12]. The median of the RNA expression was calculated and used as a threshold to distinguish the higher and lower expression within the factor groups.

\section{Tissue microarray (TMA) and Immunohistochemistry (IHC)}

TMA blocks were established as described previously [13]. Briefly, TMA blocks were obtained with $1.0 \mathrm{~mm}$ diameter of representative regions, identified with hematoxyline-eosin (H.E) staining, of each case from 194 patient surgical specimen. The cores were carefully selected on H.E stained sections and inserted into new paraffin blocks using Tissue Arrayer Minicore (ALPHELYS,Plaisir, France). The sections with $5 \mu \mathrm{m}$ thickness were then deparaffinized with xylene, and washed by $100 \%$ ethanol, $90 \%$ ethanol, $70 \%$ ethanol and finally distilled water. The sections were primed for antigen retrieval in citrate buffer ( $\mathrm{pH}$ 6.0) using microwave heating for 5 minutes cycle. Sections were incubated with 1:80 diluted Anti-TG2 antibody (EP2957, Abcam, Cambridge, MA, USA) over night at $4{ }^{\circ} \mathrm{C}$, followed by incubation with biotin labeled goat anti-mouse IgG and HRP-conjugated streptavidin (DAKO, USA) for immunostaining. The slides were scored according to staining intensity, -(negative), + (weak positive), ++ (positive), +++ (strong positive);Positive cell rates were scored from 0 to $3,0(<5 \%), 1(5 \%-25 \%), 2(25 \%$ $50 \%), 3(>50 \%)$. The final grades were scored according to the formula, $(+) \% \mathrm{x} 1+(++) \% \mathrm{x} 2+(+++) \% \mathrm{x} 3$, with $+(<1.0),++(1.0-1.5),+++(>1.5)$.

\section{Statistical analysis}

The relative expression of TG2 was described as mean and standard deviation and compared with paired t test and Chi-square test. Survival curves were obtained by using the Kaplan-Meier method. Disease-free survival (DFS) was defined from the date of definitive surgery to the date of local or distant progression, death or the date of last follow-up. Overall survival (OS) was calculated as the time from pulmonary surgery to death or censoring. The survival curves were compared by using the log-rank test. All the statistical calculations were performed by using SPSS 13 (Chicago, IL, USA). p $<0.05$ was considered statistically significant.

\section{Author contribution}

Study design

Experiments

Data collection and analysis

Manuscript writing and revising

\section{ACKNOWLEDGMENTS}

We thanks xxx to provide helps for study design and data alalysis.

\section{CONFLICTS OF INTEREST}

The authors have no conflicts of interest to declare.

\section{GRANT SUPPORT}

This work was supported by the Natural Science Foundation of Zhejiang Province (LY13H160028), Zhejiang Provincial Medicine and Health Science Fund (NO. 2013KYA028,2015KYA035, 2017KY238, 2017KY243).

\section{REFERENCES}

1. Siegel RL, Miller KD, Jemal A. Cancer statistics, 2016. CA Cancer J Clin. 2016; 66:7-30.

2. Yang P, Allen MS, Aubry MC, Wampfler JA, Marks RS, Edell ES, Thibodeau S, Adjei AA, Jett J, Deschamps C. Clinical features of 5,628 primary lung cancer patients: experience at Mayo Clinic from 1997 to 2003. Chest. 2005; 128:452-462.

3. Howlader N NA, Krapcho M, Garshell J, Miller D, Altekruse SF, Kosary CL, Yu M, Ruhl J, Tatalovich Z, Mariotto A, Lewis DR, Chen HS, Feuer EJ, Cronin KA. SEER Cancer Statistics Review, 1975-2011. National Cancer Institute Bethesda, MD, based on November 2013 SEER data submission. 2014.

4. Shepherd FA, Tsao MS. Unraveling the mystery of prognostic and predictive factors in epidermal growth factor receptor therapy. Journal of Clinical Oncology. 2006; 24 : 1219-1220.

5. Mirsadraee S, Oswal D, Alizadeh Y, Caulo A, van Beek E Jr. The 7th lung cancer TNM classification and staging system: Review of the changes and implications. World journal of radiology. 2012; 4:128-134.

6. Botling J, Edlund K, Lohr M, Hellwig B, Holmberg L, Lambe M, Berglund A, Ekman S, Bergqvist M, Ponten F, Konig A, Fernandes O, Karlsson M, et al. Biomarker discovery in non-small cell lung cancer: integrating gene expression profiling, meta-analysis, and tissue microarray validation. Clinical cancer research : an official journal of the American Association for Cancer Research. 2013; 19:194-204.

7. Coate LE, John T, Tsao MS, Shepherd FA. Molecular predictive and prognostic markers in non-small-cell lung cancer. The Lancet Oncology. 2009; 10:1001-1010.

8. Goldstraw P, Ball D, Jett JR, Le Chevalier T, Lim E, Nicholson AG, Shepherd FA. Non-small-cell lung cancer. Lancet. 2011; 378:1727-1740. 
9. Kanters SD, Lammers JW, Voest EE. Molecular and biological factors in the prognosis of non-small cell lung cancer. The European respiratory journal. 1995; 8:1389-1397.

10. Subramanian J, Simon R. Gene expression-based prognostic signatures in lung cancer: ready for clinical use? Journal of the National Cancer Institute. 2010; 102:464-474.

11. Feng J, Sheng H, Zhu C, Qian X, Wan D, Su D, Chen $\mathrm{X}$, Zhu L. Correlation of neuroendocrine features with prognosis of non-small cell lung cancer. Oncotarget. 2016; 7:71727-71736. doi: 10.18632/oncotarget.12327.

12. Livak KJ, Schmittgen TD. Analysis of relative gene expression data using real-time quantitative PCR and the 2(T)(-Delta Delta C) method. Methods. 2001; 25:402-408.

13. Kononen J, Bubendorf L, Kallioniemi A, Barlund M, Schraml P, Leighton S, Torhorst J, Mihatsch MJ, Sauter G, Kallioniemi OP. Tissue microarrays for high-throughput molecular profiling of tumor specimens. Nature medicine. 1998; 4:844-847.

14. Griffin M, Casadio R, Bergamini CM. Transglutaminases: nature's biological glues. The Biochemical journal. 2002; 368:377-396.

15. Lorand L, Graham RM. Transglutaminases: crosslinking enzymes with pleiotropic functions. Nat Rev Mol Cell Biol. 2003; 4:140-156.

16. Stamnaes J, Pinkas DM, Fleckenstein B, Khosla C, Sollid LM. Redox regulation of transglutaminase 2 activity. The Journal of biological chemistry. 2010; 285:25402-25409.

17. Han JA, Park SC. Reduction of transglutaminase 2 expression is associated with an induction of drug sensitivity in the PC-14 human lung cancer cell line. Journal of cancer research and clinical oncology. 1999; 125:89-95.

18. Antonyak MA, McNeill CJ, Wakshlag JJ, Boehm JE, Cerione RA. Activation of the Ras-ERK pathway inhibits retinoic acid-induced stimulation of tissue transglutaminase expression in NIH3T3 cells. The Journal of biological chemistry. 2003; 278:15859-15866.

19. Boehm JE, Singh U, Combs C, Antonyak MA, Cerione RA. Tissue transglutaminase protects against apoptosis by modifying the tumor suppressor protein $\mathrm{p} 110 \mathrm{Rb}$. The Journal of biological chemistry. 2002; 277:20127-20130.

20. Milakovic T, Tucholski J, McCoy E, Johnson GV. Intracellular localization and activity state of tissue transglutaminase differentially impacts cell death. The Journal of biological chemistry. 2004; 279:8715-8722.

21. Chen JS, Agarwal N, Mehta K. Multidrug-resistant MCF-7 breast cancer cells contain deficient intracellular calcium pools. Breast cancer research and treatment. 2002; 71:237-247

22. Chen JS, Konopleva M, Andreeff M, Multani AS, Pathak S, Mehta K. Drug-resistant breast carcinoma (MCF-7) cells are paradoxically sensitive to apoptosis. Journal of cellular physiology. 2004; 200:223-234.

23. Devarajan E, Chen J, Multani AS, Pathak S, Sahin AA, Mehta K. Human breast cancer MCF-7 cell line contains inherently drug-resistant subclones with distinct genotypic and phenotypic features. International journal of oncology. 2002; 20:913-920.

24. Park KS, Kim HK, Lee JH, Choi YB, Park SY, Yang SH, Kim SY, Hong KM. Transglutaminase 2 as a cisplatin resistance marker in non-small cell lung cancer. Journal of cancer research and clinical oncology. 2010; 136:493-502.

25. Verma A, Wang H, Manavathi B, Fok JY, Mann AP, Kumar $\mathrm{R}$, Mehta K. Increased expression of tissue transglutaminase in pancreatic ductal adenocarcinoma and its implications in drug resistance and metastasis. Cancer research. 2006; 66:10525-10533.

26. Yuan L, Siegel M, Choi K, Khosla C, Miller CR, Jackson EN, Piwnica-Worms D, Rich KM. Transglutaminase 2 inhibitor, KCC009, disrupts fibronectin assembly in the extracellular matrix and sensitizes orthotopic glioblastomas to chemotherapy. Oncogene. 2007; 26:2563-2573.

27. Huaying S, Dong Y, Chihong Z, Xiaoqian Q, Danying W, Jianguo F. Transglutaminase 2 Inhibitor KCC009 Induces p53-Independent Radiosensitization in Lung Adenocarcinoma Cells. Medical science monitor : international medical journal of experimental and clinical research. 2016; 22:5041-5048.

28. Shao M, Cao L, Shen C, Satpathy M, Chelladurai B, Bigsby RM, Nakshatri H, Matei D. Epithelial-to-mesenchymal transition and ovarian tumor progression induced by tissue transglutaminase. Cancer research. 2009; 69:9192-9201.

29. Mangala LS, Fok JY, Zorrilla-Calancha IR, Verma A, Mehta K. Tissue transglutaminase expression promotes cell attachment, invasion and survival in breast cancer cells. Oncogene. 2007; 26:2459-2470.

30. Jeong JH, Cho BC, Shim HS, Kim HR, Lim SM, Kim SK, Chung KY, U1 Islam SM, Song JJ, Kim SY, Kim JH. Transglutaminase 2 expression predicts progression free survival in non-small cell lung cancer patients treated with epidermal growth factor receptor tyrosine kinase inhibitor. Journal of Korean medical science. 2013; 28:1005-1014.

31. Choi CM, Jang SJ, Park SY, Choi YB, Jeong JH, Kim DS, Kim HK, Park KS, Nam BH, Kim HR, Kim SY, Hong KM, and Korean Thoracic Oncology Research Group (KTORG). Transglutaminase 2 as an independent prognostic marker for survival of patients with non-adenocarcinoma subtype of non-small cell lung cancer. Molecular cancer. 2011; 10:119. 